\title{
Redesigning Taman Hutan Kota PLN Medan (City Park) According to People's Preferences
}

\author{
Rani Aurora Barus ${ }^{1 *}$, Siti Nurkholila Hafni ${ }^{1}$, and Dwiki Alfajar ${ }^{1}$ \\ ${ }^{1}$ Department of Architecture, Universitas Pembangunan Panca Budi, Medan, Indonesia
}

\begin{abstract}
Taman Hutan Kota PLN Medan is one of important part from the city, if the park managed properly it would give a good impact to increase the quality of public space which is lead to make a positive and better contribution to people's lives who lived in the busy city like Medan. However, in reality, Taman Hutan Kota PLN cannot make a good performance as its function as public space and urban forest. To increase the level of people's happiness and develop urban quality at Medan, it is necessary to redesign Taman Hutan Kota PLN. The redesign's purpose is to fulfill the people's needs and hopes to this park and make better, satisfying, and responsive facilities to the user. Redesigning Taman Hutan Kota PLN will be based on people's preferences, perceptions, and perspectives. The preference, people's opinions, and documentation on the field will help us to discover what is the real reality and important resource for redesigning process so that the final result of the new Taman Hutan Kota PLN design can be a better park not only as public space and open green space but also as an alternative recreation facility for people in Medan.
\end{abstract}

Keyword: public space, recreation, urban forest

Received 05-07-2020 | Revised 25-07-2020 | Accepted 30-07-2020

\section{Introduction}

The good and healthy urban policy is characterized by the number of people who make the activity and interaction with other people are in the open green space area. However, if the people afraid to go out to public places like gardens, urban parks, and love to spend their time at the mall and driving to get relax, these things mean that the city has an unhealthy urban environment [1].

Taman Hutan Kota PLN is one of the open green space types (urban forest), which is located at Medan. Improving the performances of the park can be a stimulant for the government and society to accept the presence of this park not only its ecology function as open green space but also as an alternative recreation destination to entertaining people, to relax, enjoy and getting

\footnotetext{
*Corresponding author at: Jurusan Arsitektur, Fakultas Sains dan Teknologi, Universitas Pembangunan Panca Budi, Jalan Gatot Subroto Km. 4.5, Medan, Indonesia
} 
away from hustle and bustle of the big city. So that the habit and lifestyle of people from the big city can change from mall to urban park.

Compared with Taman Hutan Kota Beringin, Taman Hutan Kota PLN is less popular than Taman Hutan Kota Beringin. The problem is because the park cannot give the optimal function as public space (urban park) for the people, it is seen from the entrance of Taman Hutan Kota PLN where located on the primer road which has bad traffic and people who drive there can stop at the entrance. Also, from aesthetics aspect is also not attractive enough to get the people attention to visit the park, the facilities are out of the date and cannot give the comfort for the user, and the crucial part is this park cannot give the people to feel save if they go there, there are homeless people who slept at the gazebo of the park during the day.

So for restoring and improving the quality of the function of Taman Hutan Kota PLN Medan as an open green space (urban forest) and public space (urban park) which can be a solution as an alternative recreation destination in Medan for young people and adults, it is required to redesigning Taman Hutan Kota PLN to make a better park which can fulfill the needs and hopes of the people.

The function of the urban forest is Landscape Function, physically as protection to the natural conditions like the heat from the sun, bad smell, wind, noises, bad views, and as the place for people to make social interaction with others [2]. Ecology Function, the major oxygen contributor to the human being as well as to lower the city weather and to increase the humidity, decrease the air and noises pollution, protect and save the supply of the groundwater and prevent its pollution, and also the place for the animal to live [3]. Aesthetics Function, make the city more beautiful from the visual of the vegetation in the urban forest [4].

The urban park is a public space for the people, as an interaction center to people to communicate as formal or informal; as a divider, the building area surrounding the park, also as transit space for the people to move to another direction; as city lungs, and also as the evacuate place for people if the disaster happens [5].

Society satisfaction is the most important goal according to the process of designing a public space, so the preference and perspective of the people's needs and wants is the main resource to be the foundation to reach the satisfaction [6]. Preference is the result of the perception; perception appears because there is the interaction between the subject and the object [7]. Perception is one of the physical-physics processes that humans will receive to get information about a certain environment [8] and form sense for it. In the perception process, it will need permanent knowledge, experience, and interpretation.

Environmental preference is the result of human perception and behavior in that environment. It is a human response to the surroundings, which depends on how each human makes perception 
and describes thar environment [9]. One human perception of their surrounding is about space, revealed by the process of comparing one environment to another environment [10]. That comparison result will lead the user to decide which one is more comfortable or more beautiful, etc. These people's preferences will create an evaluation of the public space and will make people respond to give what their needs and wants as a solution to it.

\section{Methodology}

The research location is in Taman Hutan Kota PLN, the area located on Sudirman street Medan. This Research location selection based on the consideration of the strategic location, and the current design of the park is needed to be improved, so the research team has the opportunity to develop this park (Figure 1).

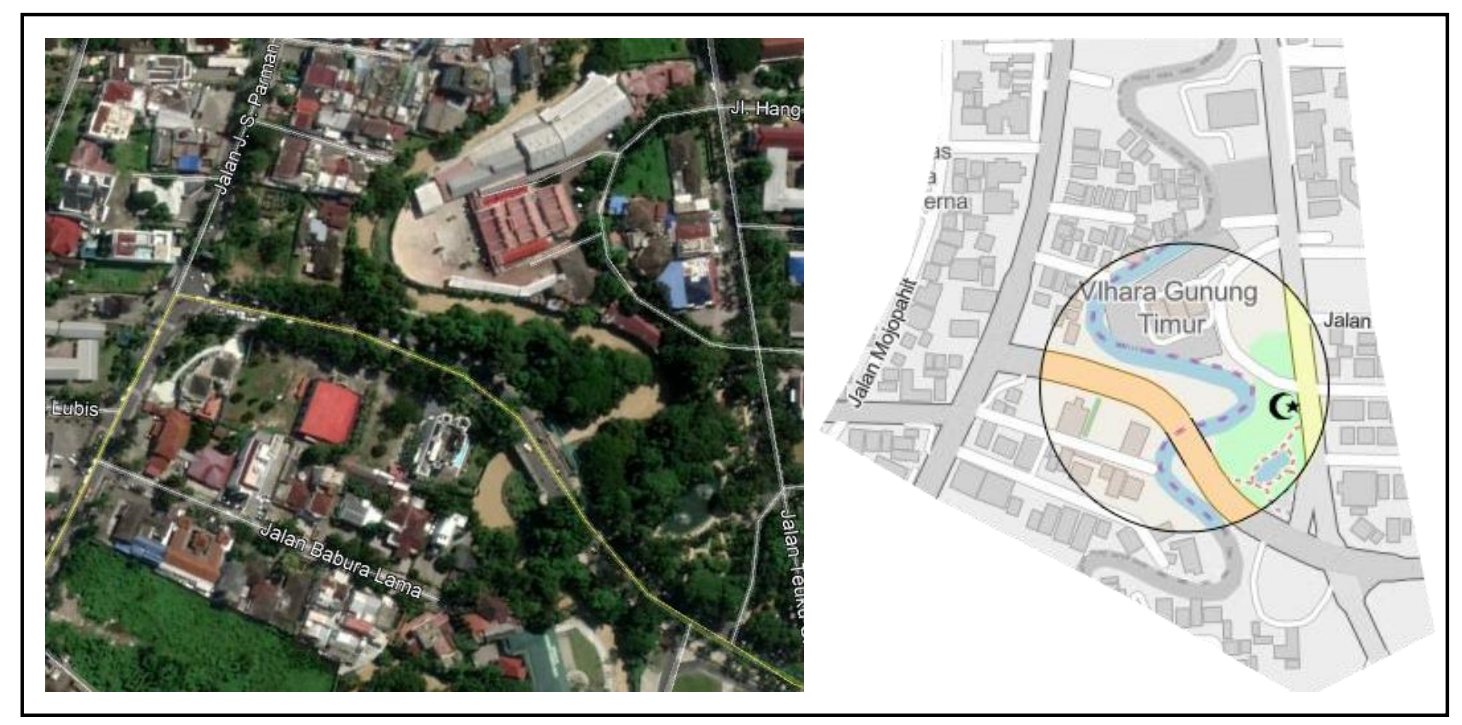

Figure 1 Location of Taman Hutan Kota PLN

(Source: earth.google.com)

The research methods used descriptive and qualitative, which aim to know and discover people perception and preferences according to their needs and wants for the design of the park, the opinions will be the resource data for redesigning Taman Hutan Kota PLN, the methods base on Design Process Booth [11] there are 7 (seven) steps: project acceptance, research, and analysis, design, construction drawing, implementation, post-construction evaluation maintenance, dan maintenance. However, in this research is adjusted to only two steps, there are:

Research and Analysis

Collecting data, in this step, we will collect the physical data and user data. According to Camic, P. M et al., (2003) [12] the collecting data have some steps there are, observation (direct observation to the location to see the existing and real condition), interview (asking the respondents), documentation (collecting the photos as the prove and resource for the research), questionnaire (giving the written question to the respondents), and literature view. Analysis 
data, the next step is to analyze the resource from the collecting data, and the analysis result is divided as physical analysis and user analysis [12].

Design

This step is started with data interpretation and then organize the program. The result will be the resource to the design process and change into the concept and the new design Taman Hutan Kota PLN.

\section{Result and Discussion}

Physical Analysis

Taman Hutan Kota PLN Medan is located between Sudirman road and Deli river. There is only one way to reach the park; we can get to the park using the sidewalk on Sudirman road and then arrived at the main entrance, which located in the south area of the park. Usually, the entrance is locked, but we can go to the inside the park from the gap between the entrance and the hedge. We are going down inside with the stairs and the stairs connected directly to the jogging track.

The jogging track makes the circulation pattern to the user of this park; unconsciously, the user will be lead to get around this park by the jogging track. The physical condition of the jogging track is using a paving block as material. Another circulation happens when the user wants to reach another facility like a gazebo and bench park (Figure 2).

The average type of vegetations of Taman Hutan Kota PLN Medan are big trees with the large diameter of the tree trunk, another vegetations in this park are small trees and bamboo trees type. The vegetation spread all around the park, which makes the density of the vegetation is enough to resist the heat of the sun directly, even though the park still has enough light. The park has the ground contour; in some parts of the park, there is a mound or uneven ground.

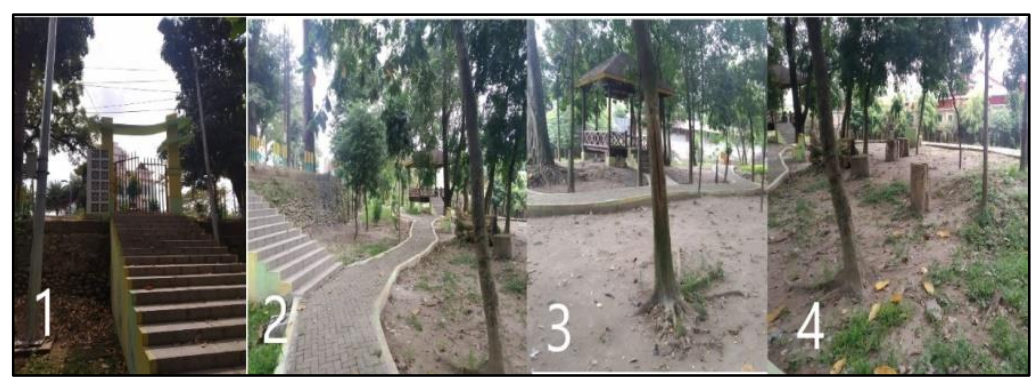

Figure 2 (1) Entrance, (2) Jogging Track, (3) Vegetations, (4) Ground Contour

The existing facilities are only just jogging track, bench park, and gazebo, so the kind of activities that happen in this park is only a few. The reality the gazebo used by homeless people as their rest place, jogging track only just for the circulation area not for exercise or running 
area, another activity is people usually do fishing there, there is no access to go down from the park, so people just jump to more close and reach the river.

The existing view in the north side showing the Vihara Gunung Timur, for the east side showing the Deli river and in this side, we can see Taman Hutan Kota Beringin across the park, the west view showing only trees and settlement surrounding the park, and the south side showing Sudirman road and across of it, there is settlement too (Figure 3).

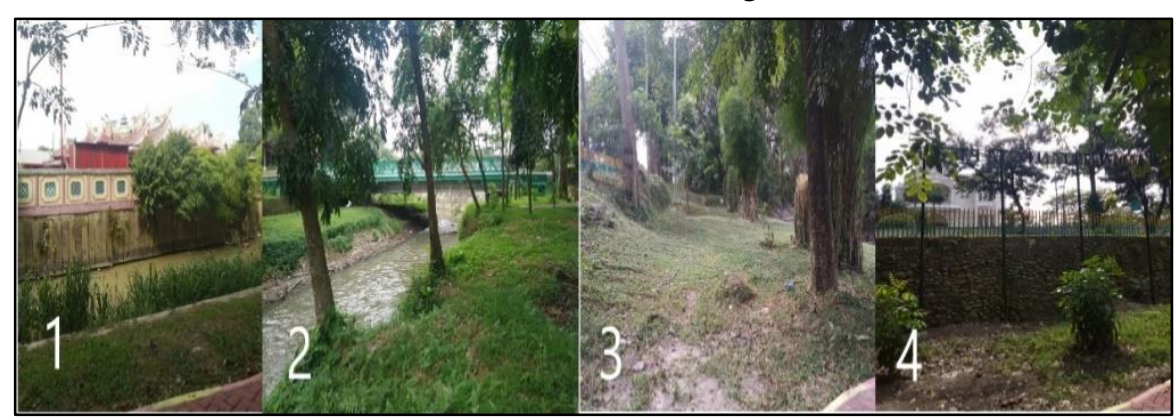

Figure 3 (1) North View (2) East View (3) West View (4) South View

User Analysis

The questionnaire was given to 81 people who are around at Taman Hutan Kota PLN Medan; the data was taken for seven days (Table 1). Divided into three categorized, there are kids/teens, adults, and parents. After the interview and the questionnaire are finished, the result reveals that the people opinions according to Taman Hutan Kota PLN are the park is quiet and people rarely seen to do something in that park, this is because the existing facilities are less attractive and cannot provide the needs and wants of the people. The activities are only about fishing, sitting, and resting places for the homeless. Based on the interview, the people want Taman Hutan Kota PLN Medan can get more variant interesting facilities and change the design to more creative and colorful so the Taman Hutan Kota PLN can be revived. The Details of the result of people's preferences to Taman Hutan Kota PLN Medan can be seen in Figures 4 and 5.

Table 1 Respondent Questionnaire Data

\begin{tabular}{lccc}
\hline \multirow{2}{*}{ Date } & \multicolumn{3}{c}{ Total Respondents/day } \\
\cline { 2 - 4 } & $\begin{array}{c}\text { Kids/Teens } \\
(9-18 \text { y.o })\end{array}$ & $\begin{array}{c}\text { Adults } \\
(16-30 \text { y.o })\end{array}$ & $\begin{array}{l}\text { Parents } \\
(\leq 31 \text { y.o })\end{array}$ \\
\hline Monday, May 25, 2020 & 2 & 5 & 3 \\
\hline Tuesday, May 26, 2020 & 2 & 3 & 4 \\
\hline $\begin{array}{l}\text { Wednesday, May 27, } \\
2020\end{array}$ & 0 & 2 & 0 \\
\hline Thursday, May 28, 2020 & 1 & 4 & 3 \\
\hline Friday, May 29, 2020 & 2 & 6 & 4 \\
\hline Saturday, May 30, 2020 & 7 & 11 & 8 \\
\hline Sunday, May 31, 2020 & 4 & 7 & 5 \\
\hline
\end{tabular}




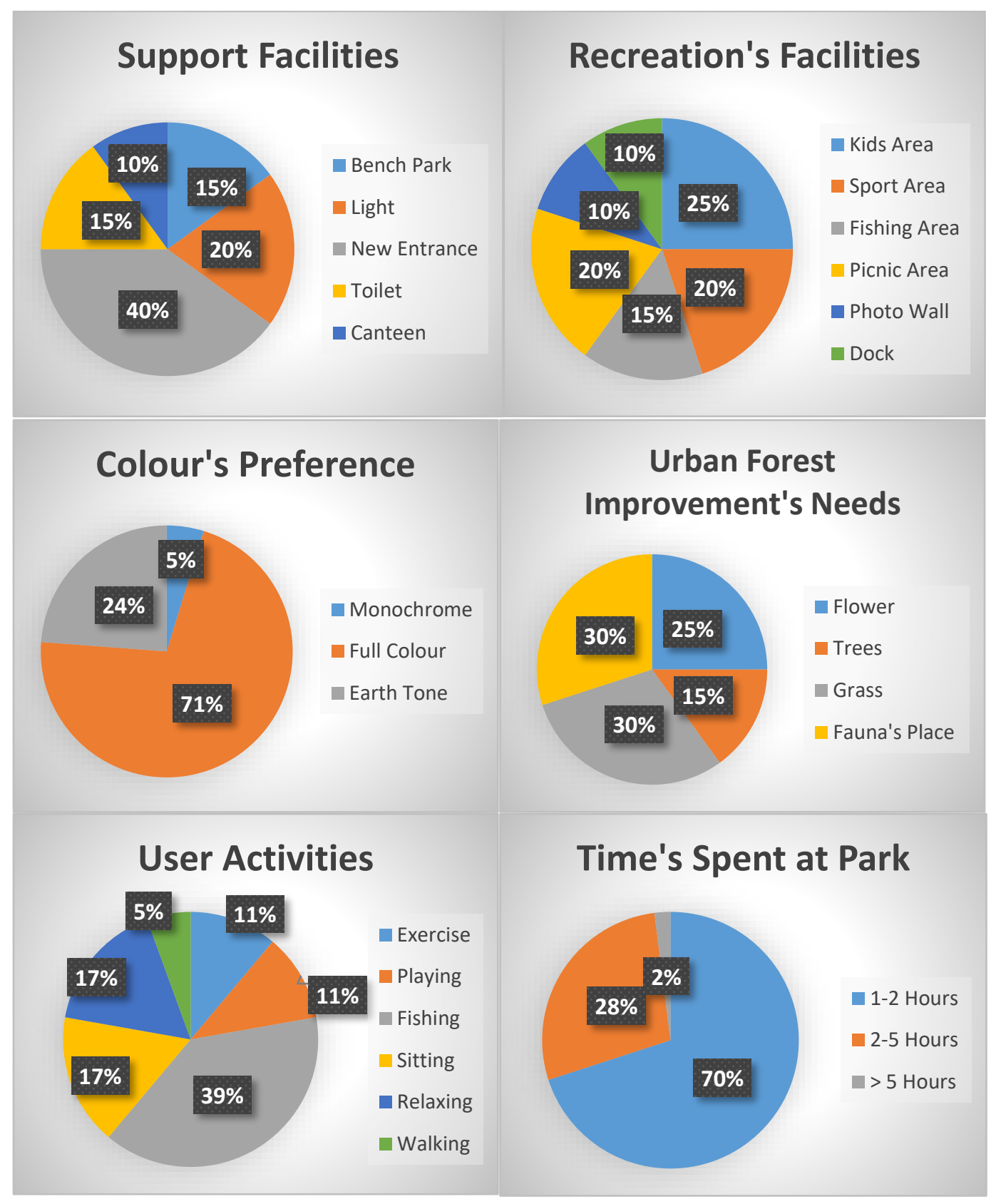

Figure 4 People's Preference for The New Taman Hutan Kota PLN

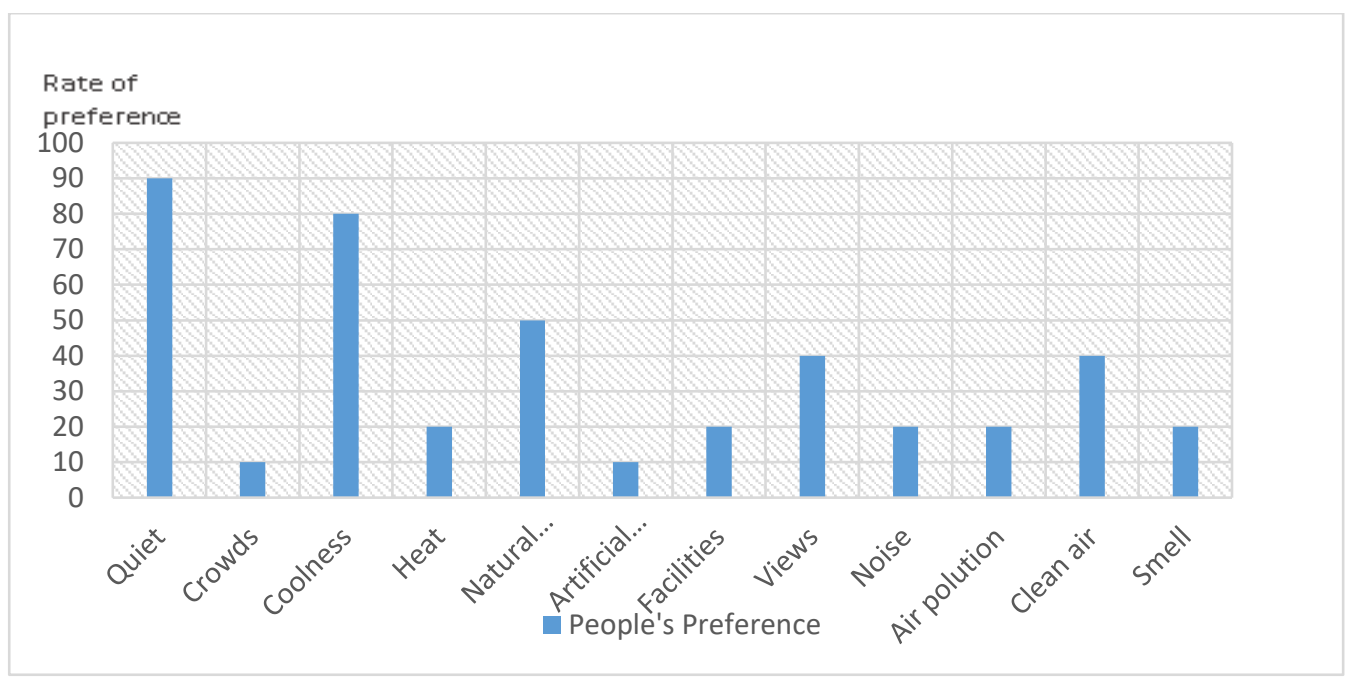

Figure 5 People's Preference For The Existing Condition of Taman Hutan Kota PLN 
Concept

The basic concept of redesigning Taman Hutan Kota PLN applies the metaphor architecture, a design approach based on the name of the park "Taman Hutan Kota PLN", PLN (Perusahaan Listrik Negara) can be interpreted and defined as an electricity source, the electricity can be provided to people's home by cable and wire, the function of cable and wire unite the people's hope to get the light at their homes. This metaphor concept is to form the reflection of the cable and the wire to make the base shape of the design so people can easily get the meaning behind it as a value for society and the identity of the park (Table 2-3 and Figure 6-10).

Table 2 Facility Requirements Program for Redesigning Taman Hutan Kota PLN

\begin{tabular}{|c|c|c|}
\hline $\begin{array}{l}\text { Influential Element } \\
\text { (Nasution, 2011) }\end{array}$ & Existing & Solution Needs \\
\hline Accessibility & $\begin{array}{l}\text { There is only one way to } \\
\text { enter. }\end{array}$ & Make a new entrance \\
\hline Public Space Area & $\begin{array}{l}\text { All part of the park is } \\
\text { public space }\end{array}$ & Enough \\
\hline Facilities & $\begin{array}{l}\text { Gazebo, Jogging Track, } \\
\text { Bench Park }\end{array}$ & $\begin{array}{l}\text { Expansion jogging track area, addition } \\
\text { for sports area, fishing area, fauna's } \\
\text { place, and canteen }\end{array}$ \\
\hline Recreation Function & Not available & $\begin{array}{l}\text { Kids area, sitting/picnic area, dock, } \\
\text { open stage, photo wall }\end{array}$ \\
\hline Vegetation & Trees & Flower and grass \\
\hline Kebersihan & Not available & Toilet and garbage bin \\
\hline Ete & Less Attractive & $\begin{array}{l}\text { Using the attractive color and } \\
\text { decorative shape for the facilities }\end{array}$ \\
\hline
\end{tabular}

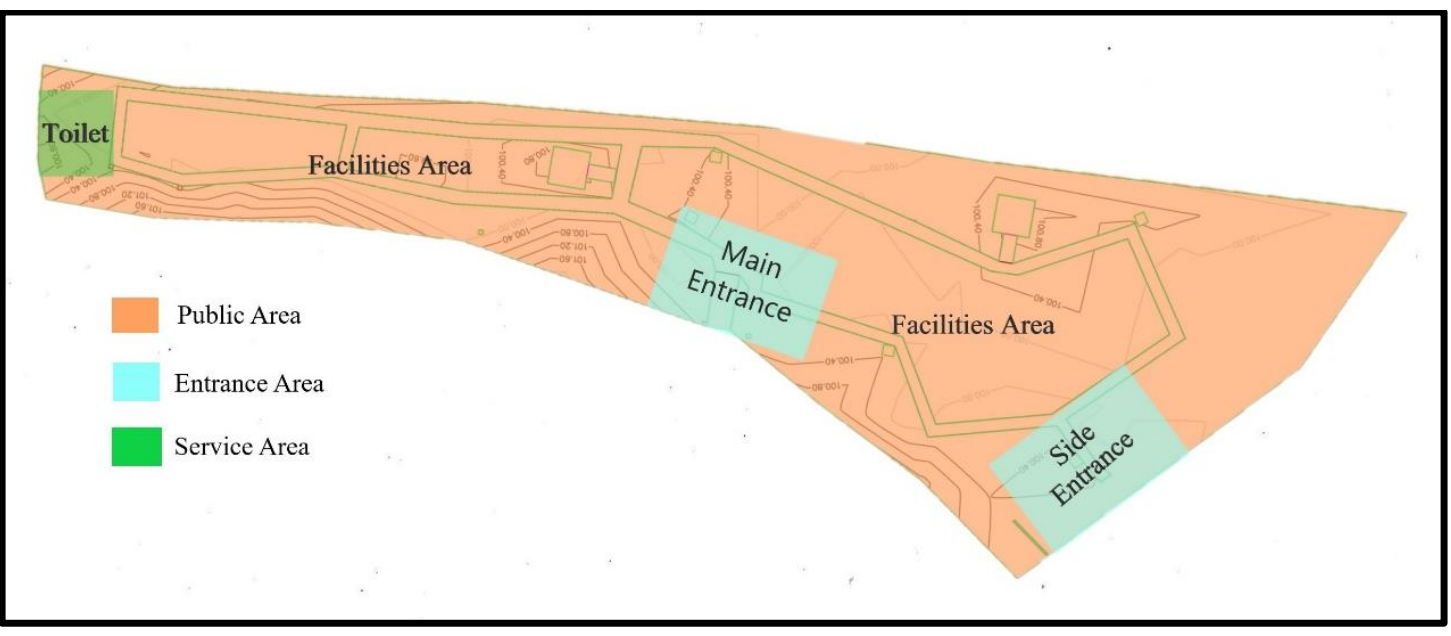

Figure 6 Zoning Concept 
Table 3 Facilities Zoning Divison

Public Area

Entrance Area

Service Area

\begin{tabular}{lcc}
\hline Gazebo, Jogging Track, Bench Park, & Main Entrance and & Toilet \\
Picnic Area, Open Stage, Kids \& Sports & Side Entrance & \\
Area, Fishing Area, Dock, Birds Nest & \\
(Fauna's Habitat) Area, Garbage Bin & & \\
\hline
\end{tabular}

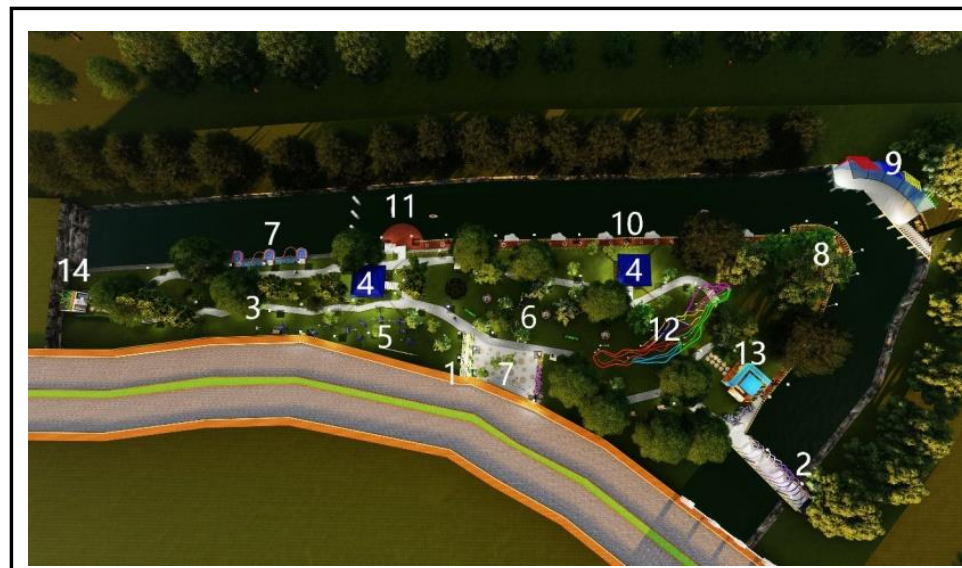

Caption :

1.Main Entrance 2. Side Entrance

3. Jogging Track 4. Gazebo

5. Sport Area 6. Kids Area

7. Photo Wall 8.Sitting/Picnic Area

9. Open Stage 10. Fishing Area

11. Dock 12. Bird Nest

13. Canteen 14. Toilet

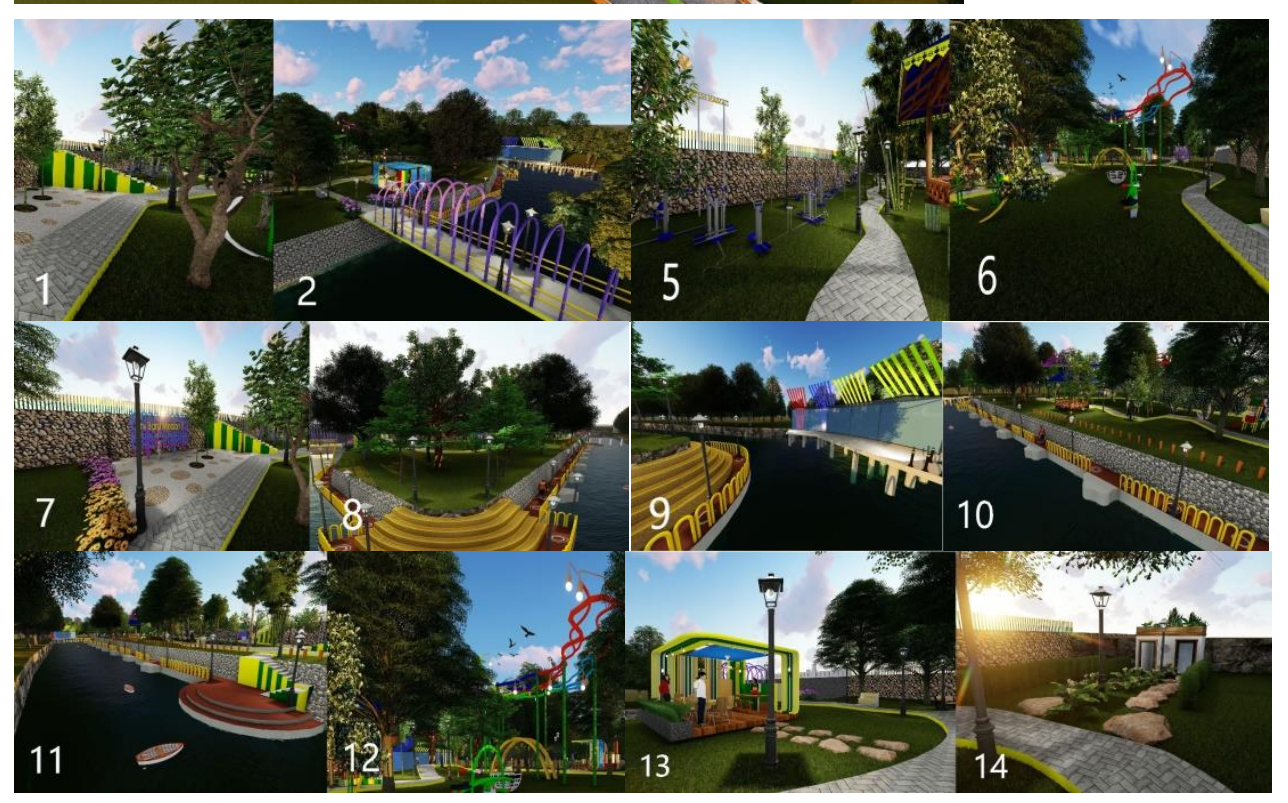

Figure 7 Facilities Mapping Area

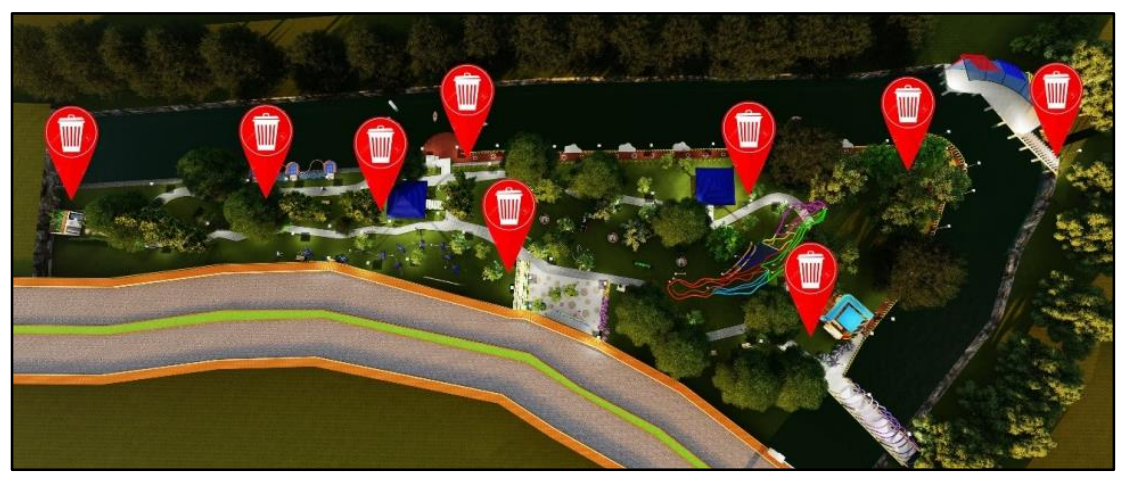

Figure 8 Garbage Bin Map at Taman Hutan Kota PLN 


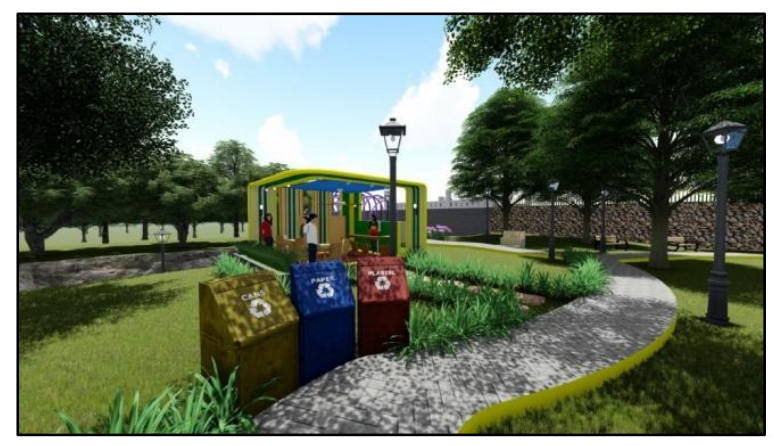

Figure 9 Garbage Bin Detail

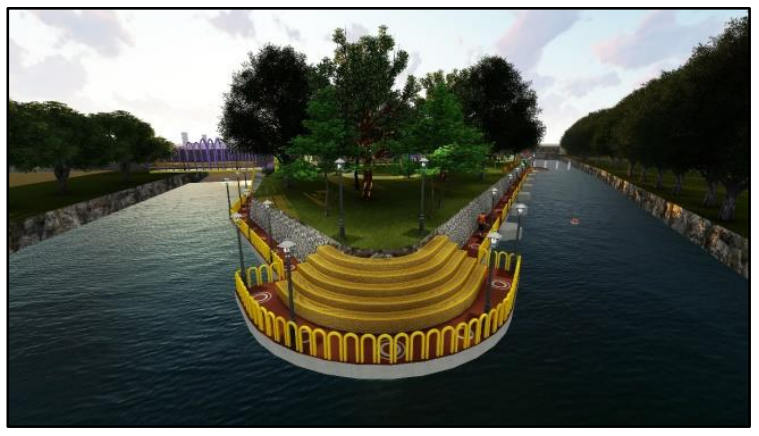

Figure 10 Perspective Result of Redesigning Taman Hutan Kota PLN

\section{Conclusion}

Redesigning Taman Hutan Kota PLN Medan have priority goal to fulfill the facilities that can support the needs and wants of the people to come to the urban park, so the main function of the park as a public space can be increased and also the park can become the solution as an alternative recreation destination for the society. The increasing visitors and performance of the park are expected to make the level of people's happiness rise and make urban growth to a healthy and good level. The redesign of the Taman Hutan Kota PLN Medan based on the good criteria of public space according to Palicki (2015) [13] there is, easily accessible location, the information about the park is easy to get, looking good inside and outside the park, capable of doing a lot thing in the park, the user feels save and comfort to be around the park, have a good environment, the place that people can do social interaction to others and to express the art.

\section{REFERENCES}

[1] H. Frumkin, L. Frank, and R. J. \& Jackson, Urban sprawl and public health: Designing, planning, and building for healthy communities.: Island Press, 2004.

[2] E. G. McPherson et al., "Quantifying urban forest structure, function, and value: the Chicago Urban Forest Climate Project.," Urban ecosystems, vol. 1, no. 1, pp. 49-61, 1997.

[3] C. Dobbs, F. J. Escobedo, and W. C. \& Zipperer, "A framework for developing urban forest ecosystem services and goods indicators," Landscape and urban planning, vol. 99, no. 3-4, pp. 196-206, 2011.

[4] C. Ordóñez and P. N. \& Duinker, "eological integrity in urban forests," Urban Ecosystems, vol. 15 , no. 4, pp. 863-877, 2012. 
[5] E. Eriksson, T. R. Hansen, and A. \& Lykke-Olesen, "Reclaiming public space: designing for public interaction with private devices," in the 1st international conference on Tangible and embedded interaction (pp. 31-38), 2007.

[6] L. Bergefurt et al., "Loneliness and life satisfaction explained by public-space use and mobility patterns," International journal of environmental research and public health, vol. 16, no. 21, p. 4282, 2019.

[7] A. Verlič, A. Arnberger, A. Japelj, P. Simončič, and J \& Pirnat, "Perceptions of recreational trail impacts on an urban forest walk: A controlled field experiment," Urban forestry \& urban greening, vol. 14, no. 1, pp. 89-98, 2015.

[8] M. Hilbert, "Toward a synthesis of cognitive biases: how noisy information processing can bias human decision making," Psychological Bulletin, vol. 138, no. 2, p. 211, 2012.

[9] C. K. Or, V. G. Duffy, and C. C. \& Cheung, "Perception of safe robot idle time in virtual reality and real industrial environments," International Journal of Industrial Ergonomics, vol. 39, no. 5, pp. 807-812, 2009.

[10] C. P. Lueg, "Characteristics of human perception and their relevance when studying information behavior," Journal of Documentation, 2014.

[11] M. Carmona, "The place-shaping continuum: A theory of urban design process," Journal of Urban Design, vol. 19, no. 1, pp. 2-36, 2014.

[12] P. M. Camic, J. E. Rhodes, and L. E. \& Yardley, Qualitative research in psychology: Expanding perspectives in methodology and design.: American Psychological Association, 2003.

[13] S. Palicki, "Multi-criteria assessment of public space from the social perspective," Real Estate Management and Valuation, vol. 23, no. 4, pp. 24-34, 2015. 